\title{
Olfactory and Taste Dysfunction as an Initial Symptom of COVID-19
}

\author{
Altuğ Özagar ${ }^{1}$ (D) , Senem Almaç Deniz ${ }^{1}$ (D)
}

${ }^{1}$ Acıbadem Dr. Şinasi Can (Kadıköy) Hospital, Department of ENT, Istanbul, Turkey

Altuğ ÖZAGAR, Asst. Prof. Dr. Senem ALMAÇ DENIZ, M.D.

Correspondence: Altuğ Özagar Acibadem Dr. Şinasi Can (Kadıköy) Hospital, Department of ENT, Istanbul, Turkey Phone: +902165444444 E-mail: altugozagar@gmail.com

Received

\section{ABSTRACT}

The coronavirus assumed to have originated in Wuhan China, has infected millions of people since December 2019, resulting in a pandemic. Recent changes in symptoms are observed in Covid-19 positive patients, whose symptoms were reported as fever, myalgia and cough in the earlier cases. In this paper we presented two cases where the initial symptom was loss of taste and smell sensation. Both of these patients were diagnosed pneumonia though neither of them had cough nor fever. Considering the positive outcomes with medical treatment, we claim these patients with the only symptom, loss of smell and taste, should be tested for Covid-19.

Keywords: Covid-19, pandemic, olfactory dysfunction, taste dysfunction

\section{COViD-19: Ilk Semptom Olarak Koku ve Tat Disfonksiyonu}

ÖZET

Aralık 2019'da Çin'in Wuhan kentinden kaynaklandığı düşünülen ve milyonlarca kişinin enfekte olmasına neden olan koronavirus bir pandemiye yol açmıştır. Enfeksiyonun ilk dönemlerinde sıklıkla görülen semptomlar ateş, miyalji ve öksürük olarak bildirilmiştir. Biz bu yazıda başlangıç bulguları olarak sadece koku ve tat alma fonksiyonunda kaybolma şikayeti ile gelen iki hastayı inceledik. Testleri pozitif çıkan ve pnömoni tanısı konan hastalarda öksürük ve ateş görülmedi. Sadece tat ve koku duyularının kaybolduğu hastaların mutlaka test ile taranması gerektiğini düşünmekteyiz.

Anahtar Sözcükler: Kovid-19, pandemi, koku disfonksiyonu, tat disfonksiyonu 
V iral and bacterial upper respiratory infections are amongst the most researched diseases. For acute respiratory distress syndrome (ARDS), the major pathogens are influenza, respiratory syncytial virus (RSV), rhinovirus, coronavirus and adenovirus (1). The so-called novel coronavirus, SARS-CoV-2, assumed to be originated in Wuhan, China, has already infected millions of people in a 3 month period. The early papers reported fever (98\%), cough (76\%), myalgia and fatigue $(44 \%)$ as the most common symptoms of COVID-19 disease caused by SARS-CoV-19. Sputum production (28\%), headache ( $8 \%)$, hemoptysis (5\%) and diarrhea (3\%) are the less reported other symptoms (2). In this article, we will discuss 2 cases diagnosed within a week in March 2020.

\section{Report of cases}

Case 1. A 23-year-old female patient came with a loss of taste and smell sensation for a week. She reported she came from abroad 13 days ago. PCR tested positive for SARS-Cov-2, she had a CT scan done which revealed a crazy-paving pattern infiltration (Fig 1). Treatment was started by hospitalization due to her pneumonia. She was discharged on the 7th day, immediately after her CT findings got better. She informed us later that her loss of taste recovered 1 week, smell 2 weeks after the treatment began.
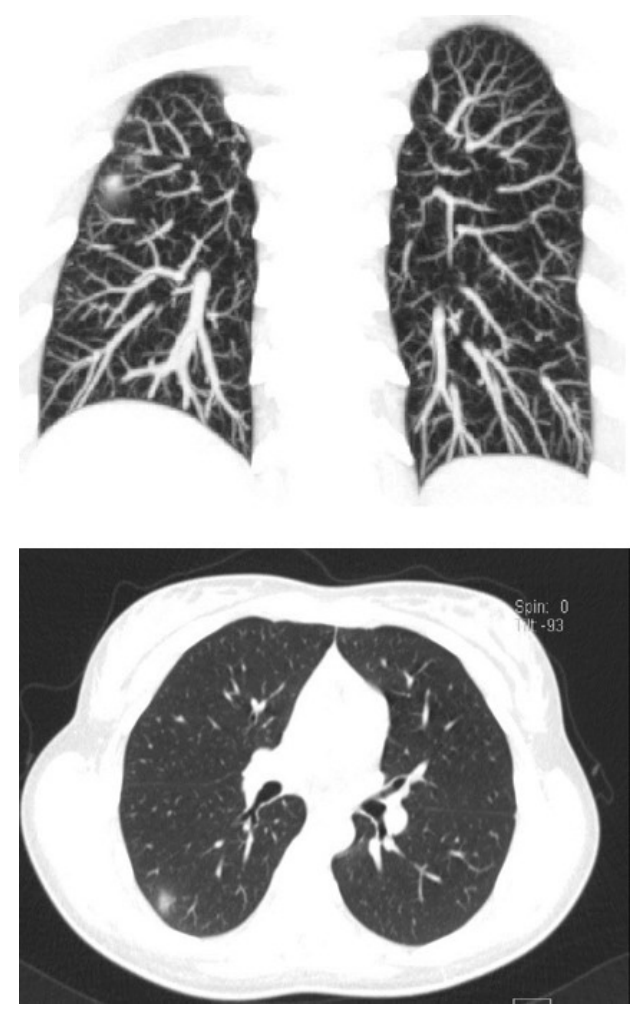

Figure 1. ŞEKIL 1 Figure 1 Thorax Computed Tomographic Image of Coronal and Axial Section Nodular opacity on the periphery of the right sided lung
Case 2. A 55-year-old female patient came with complaints of feeling tired and loss of taste and smell sensation for a week. Her thorax CT revealed a crazy-paving pattern and immediate treatment was started (Fig 2). She was tested positive for SARS-CoV-2. She was transferred to ICU because of a decrease in oxygen saturation and expansion of infiltrated areas in thorax CT. She is extubated after 2 weeks of intubation and discharged from ICU.

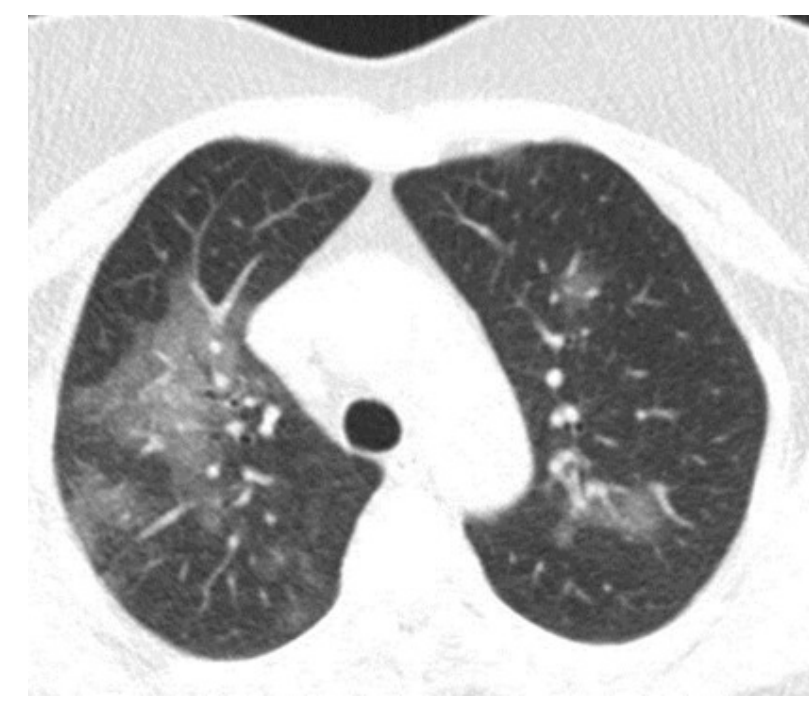

Figure 2. Lung Computed Tomographic Image of Axial Section Ground glass opacification on both sides.

\section{Discussion}

The most common symptoms since the beginning of the pandemic are fever, cough and myalgia in COVID-19 patients. These patients are mostly examined in emergency and internal medicine clinics of the hospitals. However, these 2 patients were referred to our otolaryngology clinic; loss of taste and smell sensation was the only complaint and no sign or symptom of infection was detected in one of them, and was the predominant complaint in the other who also had a slight fatigue. Both of their PCR tests came back positive for COVID-19 and had the typical crazy-paving pattern in thorax CT. These two patients were hospitalized and treated accordingly.

In literature, the most common pathogen causing postviral olfactory disorders is rhinovirus; though Ebstein Barr Virus, coronavirus and parainfluenza are also detected as other pathogens $(3,4)$. It is assumed that the virus invades the central neural system through olfactory neuroepithelium and pathway, though the exact pathophysiology is not clearly known (5). Yamagishi et al, in a 13 patient 
study, showed a decrease in the number of olfactory receptors and nerve bundles after upper respiratory infections (6). In some animal studies, it is shown that inoculation of various viruses intranasally causes a destruction in central olfactory pathways (7-8). Recently, Steven et al identified bitter taste receptors on human airway smooth muscle cells (9). We assume it is possible the olfactory cells contain angiotensin-converting enzyme 2 receptors since it is known that SARS-CoV-2 (enters host cells of the human airway via these receptors) performs its action on the human airway through these receptors.

The patients being tested positive with the symptom, loss of smell and taste sensation may suggest the virus might have developed a different behaviour since this symptom wasn't reported previously.

As it is seen, all the patients came with the same symptom, but each progressed differently, which suggests disease progress might be independent from symptoms due to various factors. In patients with loss of taste and smell sensation only, COVID-19 must be kept in mind.

\section{Conclusion}

Data regarding Covid-19 have changed substantially since the beginning of the pandemic. In the early days, the defining symptoms were considered to be fever, dry cough and shortness of breath. In this paper, we presented only two of the many patients whose initial complaint was a loss of smell and taste. We suggest that these patients could easily be overlooked if Covid-19 is not kept in mind.

\section{References}

1. Mahony JB, Petrich A, Smieja M. Molecular diagnosis of respiratory virus infections. Crit Rev Clin Lab Sci. 2011;48:217-49.

2. Huang C, Wang Y, Li X, Ren L, Zhao J, Hu Y, Zhang L, Fan G, Xu J, Gu X, Cheng Z, Yu T, Xia J, Wei Y, Wu W, Xie X, Yin W, Li H, Liu M, Xiao Y, Gao H, Guo L, Xie J, Wang G, Jiang R, Gao Z, Jin Q, Wang J, Cao B. Clinical features of patients infected with 2019 novel coronavirus in Wuhan, China.Lancet. 2020 Feb 15;395(10223):497-506.

3. Detection of parainfluenza virus 3 in turbinate epithelial cells of postviral olfactory dysfunction patients.Wang JH1, Kwon HJ, Jang YJ. Laryngoscope. 2007 Aug;117(8):1445-9.

4. Identification of Viruses in Patients With Postviral Olfactory Dysfunction Motohiko Suzuki, Koichi Saito, Wei-Ping Min, Costin Vladau, Kazunori Toida, Hirotaka Itoh, Shingo Murakami. Laryngoscope, 117:272-277, 2007

5. Stroop MG. Viruses and the olfactory system. In: Doty RL, editor. Handbook of olfaction and gustation. New York: Marcel Dekker; 1995. p. 367-94

6. Yamagishi M, Fujiwara M, Nakamura H. Olfactory mucosal findings and clinical course in patients with olfactory disorders following upper respiratory viral infection. Rhinology 1994;32:113-8
7. Perlman S, Evans G, Afifi A. Effect of olfactory bulb ablation on spread of a neurotropic coronavirus into the mouse brain. J Exp Med 1990;172:1127-32

8. Behavioural deficits and serotonin depletion in adult rats after transient infant nasal viral infection. Mohammed AK1, Magnusson O, Maehlen J, Fonnum F, Norrby E, Schultzberg M, Kristensson K. Neuroscience. 1990;35(2):355-63.

9. An SS, Liggett SB. Taste and smell GPCRs in the lung: evidence for apreviously unrecognized widespread chemosensory system. Cell Signal. 2018;41:82-88. doi:10.1016/j.cellsig.2017.02.002 